\title{
AUGMENTED REALITY PENGENALAN ORGAN DALAM MANUSIA MENGGUNAKAN METODE MARKER BERBASIS ANDROID
}

\author{
Ahmad Hamdani, Ali Mahmudi, Karina Auliasari \\ Program Studi Teknik Informatika S1, Fakultas Teknologi Industri \\ Institut Teknologi Nasional Malang, Jalan Raya Karanglo km 2 Malang, Indonesia \\ hamdani23rd@gmail.com
}

\begin{abstract}
ABSTRAK
Sebagai mahluk hidup manusia terdiri dari berbagai macam organ tubuh, untuk organ luar tubuh tentu bisa diamati secara langsung oleh mata manusia, namun tidak dengan organ dalam manusia, dimana mata manusia tak bias melihat secara organ dalam secara langsung karena perlu dilakukan pembedahan pada tubuh manusia terlebih dahulu. Berdasarkan masalah yang telah disebutkan maka penulis bermaksud untuk menggunakan teknologi yang telah dikembangkan saat ini yaitu Augmented Reality sebagai upaya untuk mengatasi masalah tersebut.

Dengan memanfaatkan teknologi ini untuk membuat Augmented Reality pengenalan organ dalam manusia menggunakan metode marker berbasis Android. Untuk pembuatan aplikasi digunakan Unity dengan Vuforia, untuk pembuatan objek 3D digunakan aplikasi Blender untuk pemodelannya

Hasil akhir dari penelitian ini berupa aplikasi Augmented Reality pengenalan organ dalam manusia menggunakan metode marker berbasis Android, pada penelitian ini penulis berhasil membuat marker yang memiliki rata-rata waktu load untuk memunculkan objek yaitu 1.58 detik. Sedangkan untuk minimal versi android untuk menggunakan aplikasi adalah Marsmellow 5.0 dengan ram 1.5 GB dan waktu load aplikasi adalah 7.86 detik. Untuk jarak detaksi dengan jarak yaitu $10 \mathrm{~cm}, 20 \mathrm{~cm}, 30 \mathrm{~cm}$, dan $40 \mathrm{~cm}$. Rata-rata waktu load tiap jarak yaitu 1.59 detik untuk $10 \mathrm{~cm}, 1.73$ detik untuk $20 \mathrm{~cm}, 2.24$ detik untuk jarak $30 \mathrm{~cm}$ dan 2.80 detik untuk jarak $40 \mathrm{~cm}$. Cahaya optimal untuk mendeteksi objek berada dikisaran antara 1050 lux sampai 7625 lux.
\end{abstract}

Kata kunci : Augmented Reality, metode marker, organ manusia.

\section{PENDAHULUAN}

Sebagai mahluk hidup manusia terdiri dari berbagai macam organ tubuh, untuk organ luar tubuh tentu bisa diamati secara langsung oleh mata manusia, namun tidak dengan organ dalam manusia, dimana mata manusia tak bias melihat secara organ dalam secara langsung karena perlu dilakukan pembedahan pada tubuh manusia terlebih dahulu. Untuk saat ini beberapa upaya yang telah dilakukan untuk menangani masalah ini yaitu melalui buku dan kit anatomi tubuh manusia atau dengan pembedahan tubuh manusia secara langsung. Untuk saat ini beberapa upaya yang telah dilakukan untuk menangani masalah ini yaitu melalui buku dan kit anatomi tubuh manusia atau dengan pembedahan tubuh manusia secara langsung. Di era masa kini citra 3D telah dimaanfaatkan dengan teknologi baru yang disebut Augmented Reality (AR). Augmented Reality (AR) merupakan teknologi yang menggabungkan citra 3D dengan dunia nyata dengan citra virtual menggunakan perantara kamera.

Berdasarkan kondisi yang banyak terjadi di lingkungan pendidikan masa kini, pembelajaran anatomi bentuk organ dalam tubuh hanya bisa dilakukan di laboratorium biologi sekolah dengan menggunakan kit anatomi tubuh atau di ruang kelas dengan menggunakan buku, melihat dengan kurikulum terbaru dunia pendidikan indonesia dimana siswa dituntut untuk aktif dalam memahami materi yang diberikan oleh sekolah. Sedangkan pembelajaran yang ada masih sangat tergantung dengan tempat atau masih terbatas dengan gambaran dari buku teks, untuk para siswa yang bertempat tinggal didesa pun ini menjadi permasalahan yang sangat sering ditemui dimana sekolah masih belum menyediakan kit anatomi tubuh manusia dan hanya menggunakan buku untuk media pembelajaran.

Oleh karena itu penulis bermaksud membuat aplikasi pengenalan organ dalam manusia menggunakan Augmented Reality berbasis Android sebagai sarana belajar dan salah satu upaya dalam membantu pembelajaran siswa menjadi lebih efektif dan menarik, sehingga siswa tak cepat bosan untuk memahami materi yang diberikan.

\subsection{Rumusan Masalah}

Berdasarkan permasalahan yang terindetifikasi diatas, maka dapat dirumuskan beberapa rumusan masalah sebagai berikut:

1. Bagaimana cara merancang dan mengimplementasikan aplikasi augmented reality pengenalan organ dalam manusia menggunakan metode marker berbasis Android sebagai media pembelajaran?

2. Bagaimana cara mengimplementasikan Marker Based Tracking pada augmented reality untuk menyampaikan informasi mengenai organ dalam manusia? 


\subsection{Tujuan}

Terdapat beberapa tujuan dari pembuatan aplikasi ini sebagai berikut :

1. Mengimplementasikan metode marker sebagai metode untuk deteksi marker pada aplikasi Augmented Reality pengenalan organ dalam manusia.

2. Mengimplementasikan teknologi augmented reality sebagai salah satu sarana pembelajaran organ dalam manusia dalam bentuk objek 3D berbasis Android.

\subsection{Batasan Masalah}

Berdasarkan pembuatan augmented reality ini terdapat beberapa batasan dalam pembuatan yaitu sebagai berikut:

1. Aplikasi ini hanya berbasis Android Lollipop 5.0.

2. Sumber data dari dan buku The Ultimate Guide Tubuh Manusia dengan penerbit oleh Bhuana Ilmu Populer, Kelompok Gramedia, Jakarta, 2018. Dan $e$ Book Buku Guru Ilmu Peengetahuan Alam kelas VIII dengan penerbit oleh Pusat Kurikulum dan Pembukuan, Balitbang, Kemendikbud.

3. Marker dapat dideteksi apabila terdapat cahaya yang cukup terang seperti cahaya lampu.

4. Aplikasi ini di buat dengan software Unity 2017.4.33, Android Studio 3.5, Blender 2.79.

5. Output berupa objek 3D model dari organ dalam tubuh manusia.

6. Aplikasi ini hanya berbahasa Indonesia.

7. Target pengguna yaitu pelajar, mahasiswa, dan masyarakat umum.

\section{TINJAUAN PUSTAKA}

\subsection{Penelitian Terkait}

Di tahun 2014, Enang Rusnandi dan kawan kawan mengembangkan media pembelajaran dengan menggunakan teknologi Augmented Reality (AR), yaitu teknologi yang menggabungkan objek virtual dua dimensi atau tiga dimensi ke dalam sebuah lingkungan nyata dan kemudian memproyeksikan objek maya tersebut secara realtime. Pada media ini pula dijelaskan materi pembelajaran berupa, nama bangun dan rumus-rumusnya. Dengan menggunakan aplikasi ini diharapkan siswa menjadi lebih tertarik mempelajari matematika khususnya pada materi bangun ruang [1].

Ditahun 2014 Muhammad Rifa'i dan kawan kawan juga manfaatkan perkembangan teknologi ini untuk media pemasaran yang iteraktif khusus nya pemasaran rumah.Augmented Reality (AR) adalah salah satu perkembangan teknologi saat ini.Augmented Reality (AR), adalah teknologi yang menggabungkan benda maya dua dimensi dan tiga dimensi kedalam sebuah lingkungan nyata tiga dimensi lalu memproyeksikan benda-benda maya tersebut dalam waktu nyata. Penelitian ini akan menerapkan teknologi AR kedalam katalog rumah berbasis Android. AR Katalog rumah berbasis andoid ini memerlukan video streaming yang diambil dari kamera sebagai sumber masukkan, kemudian aplikasi ini akan melacak dan mendeteksi marker (penanda) dengan menggunakan sistem tracking, setelah marker dideteksi, model rumah 3D muncul di atas marker seolah-olah model tersebut nyata [2].

Pada tahun 2018 Andri Wahyu Saputra beserta kawan-kawannya membuat sebuah aplikasi untuk edukasi hardware komputer berbasis teknologi Augmented Reality menggunakan Android yang di tujukan untuk pelajar dan mahasiswa dimana banyak yang mengalami kesulitan dalam mempelajari dan menghapal unit-unit komputer. Andri dan kawankawan membuat aplikasi dalam penelitian ini dengan basis sistem operasi Android sedangkan bahasa pemrograman yang di gunakan adalah $\mathrm{C} \#$ dan software game engine unity 3D dimana aplikasi ini menerapkan Vuforia sebagai SDK untuk menciptakan Augmented Reality. Untuk informasi dan penampilan objek 3D yang di sampaikan oleh aplikasi buatan Andri dan kawan-kawan yaitu proccessor, motherboard, ram, herddisk, dan vga. Untuk aplikasi ini masih menggunakan visual button yang terletak pada marker [3].

Pada tahun 2019 Anang Pramono dan kawankawan melakukan penelitian tentang media pembelajaran inovatif dan alternatif untuk mengenalkan buah-buahan kepada anak-anak dengan Augmented Reality (AR). Penelitian ini didasari oleh masalah banyaknya media pembelajaran anak yang sudah dikembangkan tetapi masih belum menggabungkan antara konsep perubahan kurikulum dan perkembangan teknologi kekinian dimana media pembelajaran yang digunakan untuk anak masih berbasis buku teks dengan metode penyampaian kelasik. Media pembelajaran yang mereka buat menggunakan kartu-kartu bergambar dan visual reality, pada kartu-kartu tersebut terdapat marker yang dapat di tangkap oleh kamera mobile device, diproses dan akan menampilkan animasi 3D buahbuahan pada layar handphone secara real time [4].

Pada tahun 2019 Agmita Clara Rosa dan kawankawan melakukan penelitian tentang rekayasa Augmented Reality planet dalam tata surya sebagai media pembelajaran bagi siswa SMP 57 palembang penelitian ini di dasari oleh masalah yaitu bagaimana cara mensimulisasi sistem tata surya dalam bentuk aplikasi sebagai media pembelajaran interaktif berbasis Android dan cara memfasilitasi siswa untuk bermain sambil belajar untuk, adapun untuk tata surya yang disimulasikan hanyalah planet yang ada di dalam gugusan bima sakti dengan menggunakan marker untuk 8 planet dan 1 matahari disertai deskripsi planet, kandungan unsur atmosfer yang ada didalam masing-masing planet. Untuk metode aplikasi yang digunakan dalam penelitian ini adalah rational unified process dan pemodelan unified modeling language (UML) [5]. 


\subsection{Dasar Teori}

\subsubsection{Android}

Android adalah sistem yang berbasis linux yang dan bersifat open source, Dirancang untuk perangkat mobile dengan touch screen seperti smartphone dan tablet. Android dikembangkan oleh Android, Inc., dengan dukungan finansial dari google, yang mana telah dibeli oleh google pada tahun 2005. Android dirilis secara resmi pada tahun 2007, bersamaan dengan didirikannya open handset alliance [6].

Dengan sifat open source yang Android, memungkinkan para develover aplikasi untuk membuat bermacam aplikasi Android baik itu aplikasi bisnis, keamanan, utilities, maupun aplikasi games. Hal ini yang menyebabkan banyak masyarakat yang memilih smartphone dengan sistem operasi Android untuk smartphone mereka.

\subsubsection{Augmented Reality}

Augmented Reality (AR) adalah suatu teknologi yang menggabungkan objek virtual 2 dimensi dan ataupun 3 dimensi ke dalam sebuah lingkungan nyata secara real time. Tidak seperti objek virtual yang sepenuhnya menggantikan kenyataan, namun Augmented Reality hanya menambahkan atau melengkapi kenyataan. Augmented reality ini menggabungkan benda-benda nyata dan virtual objek, virtual objek ini hanya bersifat menambahkan bukan menggantikan objek nyata, adapun tujuan dari Augmented Reality ini yaitu untuk menyederhanakan objek nyata dengan membawa objek maya sehingga informasi tidak hanya untuk pengguna secara langsung. Setiap pengguna yang tidak langsung berhubungan dengan user interface dari objek nyata, seperti live-streaming video [7].

\subsubsection{Augmented Reality Book}

Augmented Reality Book (AR-Book) kemudian diartikan dalam Bahasa Indonesia sebagai buku berbasis Augmented Reality. merupakan sebuah penggabungan antara buku biasa dengan teknologi Augmented Reailty. AR-Book merupakan buku yang dilengkapi dengan marker berjenis Quick Response Code (QRC) pada hampir setiap halamannya, dan yang kedua yaitu peralatan untuk mendeteksi marker dan menampilkan hasilnya. Adapun alat yang digunakan dapat berbentuk hand held display (HHD), head mounted display (HMD), virtual retinal display (VRD), atau bahkan tampilan berbasis layar biasa [8].

\subsubsection{Vuforia SDK}

Vuforia meruapakan sebuah AR SDK untuk smartphone atau perangkat mobile device untuk pembuatan aplikasi Augmented Reality yang di gunakan pada perangkat mobile, SDK ini merupakan teknologi computer vision untuk mengenali dan melacak image target dan objek 3D yang ditampilan secara real time. Software ini menggunakan kemampuan teknologi Computer vision untuk mengenali dan membuat secara individual deteksi objek yang ditangkap oleh kamera perangakat mobile secara real time. Dengan menggunakan Vuforia developer dapat membuat posisi dan orientasi objek virtual seperti model 3D dapat dilihat melalui kamera dari perangkat mobile. Sehingga terlihat bahwa objek virtual tersebut adalah bagian dari dunia nyata [9].

\subsubsection{Marker / Target}

Marker merupakan sebuah gambar berpola khusus yang sudah dikenali oleh aplikasi Augmented Reality. Dimana marker tersebut berfungsi untuk dibaca dan dikenali oleh kamera lalu dicocokkan dengan database Vuforia. Kemudian baru kamera akan mulai melakukan render objek 3D diatas marker. Dulu Marker yang bisa dikenali apliaksi Augmented Reality hanya marker dengan pola berbentuk kotak dengan bingkai hitam didalamnya. Akan tetapi seiring berkembangnya zaman banyak pengembang Augmented Reality yang dapat membuat marker dengan basis gambar [10].

\subsubsection{Pengolahan Citra Digital}

Image Processing atau pengolahan citra digital merupakan metode untuk mengolah citra atau gambar digital yang disimpan dalam bentuk 2D [11].

Pada Augmented Reality yang berbasis marker kebanyakan masih menggunakan gambar 2D sebagai image target-nya jadi diperlukan juga pengolahan citra digital agar setiap marker tak menampilkan objek 3D yang sama pada marker yang berbeda.

\section{METODE PENELITIAN}

\subsection{Blok Diagram Sistem}

Design arsitektur sistem menjelaskan tentang inputan aplikasi kemudian proses yang di lakukan oleh aplikasi dan selanjutnya menampilkan daftar output dari aplikasi, seperti tunjukkan pada Gambar 3.1.

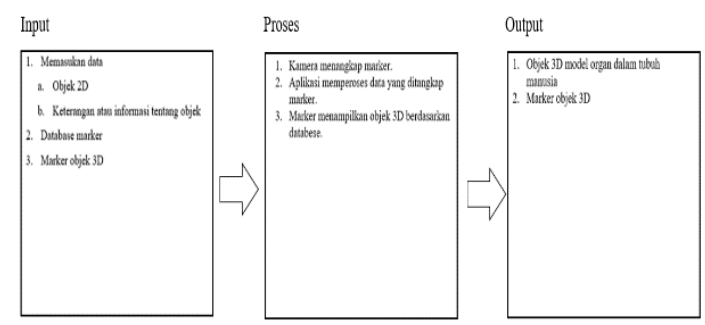

Gambar 3.6 Desain arsitektur sistem

Pada Gambar 3.1 di jelaskan yaitu input aplikasi berupa masukan data dengan dua jenis data yaitu objek 2D dan keterangan atau informasi tentang objek, inputan yang kedua yaitu databese marker, untuk inputan yang terakhir adalah marker objek 3D. pada bagian proses yang pertama adalah kamera menangkap marker, lalu di lanjutkan dengan memperoses data yang ditangkap dari marker, dan proses akhirnya adalah menampilkan objek 3D berdasarkan databese. Untuk output yang di hasilkan 
dari aplikasi ini adalah objek 3D model organ dalam tubuh manusia dan marker objek 3D.

\subsection{Activity Diagram Sistem}

Pada activity diagram digambarkan alur kerja aplikasi Augmented Reality pengenalan organ dalam manusia menggunakan metode marker berbasis Android.

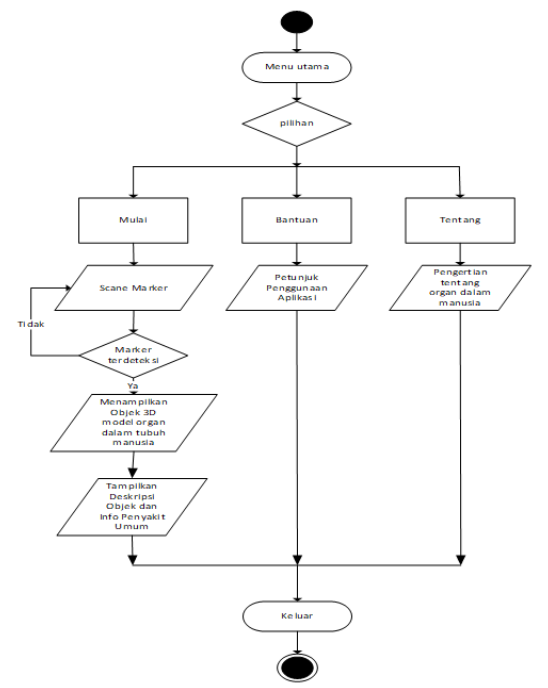

Gambar 3.7 Activity Diagram Sistem

Pada Gambar 3.2 diterangkan tentang alur penggunaan aplikasi dimana pengguna di hadapkan dengan menu utama kemudia pada menu utama terdapat beberapa tombol yaitu mulai bantuan tentang dan keluar untuk tombol muali terdapat proses scane marker kemdian deteksi marker untuk menampilkan objek 3D model organ dalam tubuh manusia setelah objek ditampilkan pada halaman scan akan muncul tentang informasi objek dan beberapa penyakit umum yang menyerang organ dalam, untuk tombol bantun akan ditampilkan petunjuk penggunaan aplikasi, sedangkan untuk tombol tentang akan menampilkan tentang pengertian organ dalam manusia, untuk megakhiri aplikasi di gunakan tombol keluar, jadi tombol keluar akan menjadi akhir dari aktivitas pengguna aplikasi.

\subsection{Flowchart Augmented Reality}

Flowchart penampilan proses penggunaan Augmented Reality pada aplikasi Augmented Reality pengenalan organ dalam manusia menggunakan metode marker berbasis Android.

pada Gambar 3.3 untuk memulai aplikasi pengguna mengakses menu utama aplikasi kemudia membuka kamera smartphone dengan menggunakan rombol mulai lalu dilanjutkan dengan pendeteksian marker setelah marker dideteksi selanjutnya dilakukan proses pencocokan marker jika marker cocok dengan data dari database kemudian dilakukan rendering objek 3D model organ dalam tubuh manusia setelah render selesai barulah ditampilkan objek 3D organ dalam tubuh manusia setelah objek berhasil ditampilakan maka ditampilkan juga informasi tentang objek dan juga beberapa informasi tentang penyakit umum yang menyerang organ dalam dan kemudian proses berakhir.

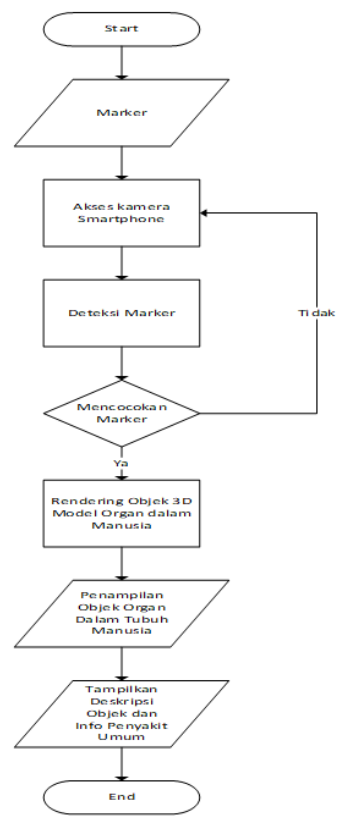

Gambar 3.8 Flowchart Augmented Reality

\section{HASIL DAN PEMBAHASAN}

\subsection{Pengujian Tampilan Awal}

Halaman menu utama merupakan tampilan pertama aplikasi setelah aplikasi dijalankan, untuk pengujianya ditunjukan pada Gambar 4.1.

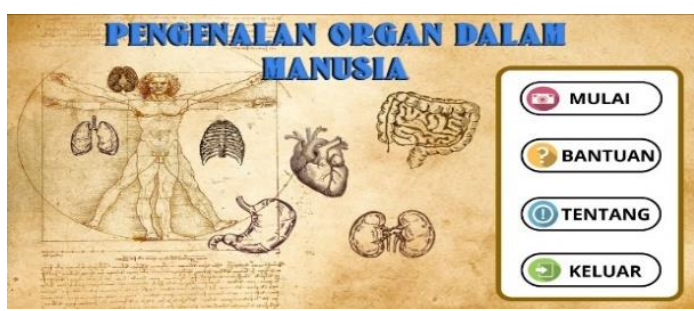

Gambar 4.1 Pengujian fitur menu utama

Pada Gambar 4.1 ditampilkan halaman menu utaman dengan 4 tombol yang diletekan di sisi kanan halaman, tombol-tombol itu antara lain yaitu tombol mulai, tombol bantuan, tombol tentang, dan tombol keluar.

\subsection{Fitur Halaman Bantuan}

Halaman bantuan merupakan halaman yang menerangkan petunjuk penggunaan aplikasi Augmented Reality pengenalan organ dalam manusia, untuk mengaktifkan fitur Halaman bantuan harus menekan tombol bantuan dihalaman menu utama. Pengujian fitur halaman bantuan ditunjukan pada Gambar 4.2. 


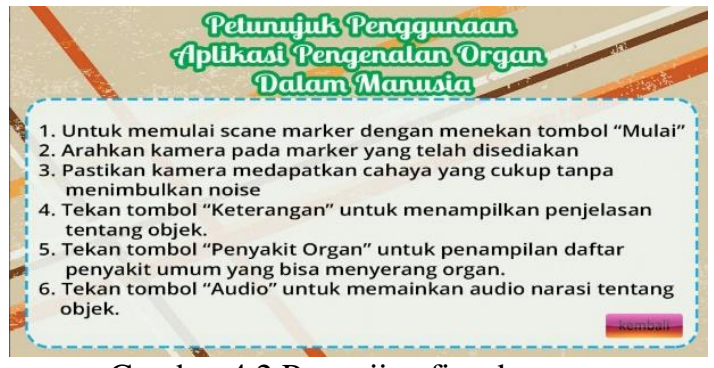

Gambar 4.2 Pengujian fitur bantuan

Pada Gambar 4.2 ditunjukan halaman fitur bantuan, pada bagian tengah halaman dijelaskan tentang tata cara menggunakan aplikasi Augmented Reality pengenalan organ dalam manusia menggunakan metode marker berbasis Android.

\subsection{Fitur Halaman Tentang}

Halaman tentang berisikan info developer aplikasi beserta dengan fotonya, untuk mengaktifkan fitur tentang user harus menekan tombol tentang dihalaman menu utama. Pengujian fitur halman tentang ditunjukan pada Gambar 4.3.

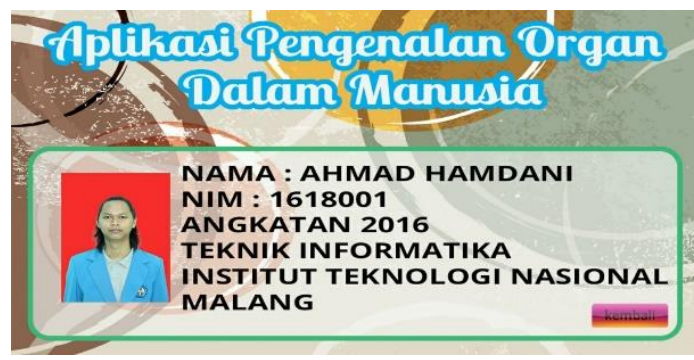

Gambar 4.3 Pengujian fitur tentang

Pada Gambar 4.3 di tampilkan halaman fitur tentang yang menampilkan informasi tentang developer aplikasi. Pada bagian bawah kanan terdapat tombol kembali.

\subsection{Fitur Halaman Scane Marker}

Halaman scane objek merupakan halamn untuk melakukan scane marker dan penampilan objek 3D organ dalam manusia, untuk mengaktifkan fitur scane marker user harus menekan tombol mulai dihalaman menu utama. Pengujian fitur halaman scane marker ditunjukan pada Gambar 4.4.

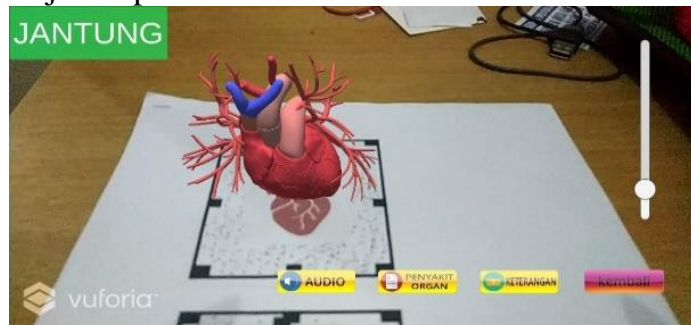

Gambar 4.4 Pengujian fitur scan marker

Pada Gambar 4.4 ditampilkan halama scane marker, untuk bagian atas kiri ditampilkan nama objek. Kemudian pada bagian samping kanan diletakkan slider untuk melakukan scalling pada objek. Pada bagian bawah kanan terdapat tombol kembali, disebelah tobol kembali terdapat tombol keterangan, disamping dengan tombol keterangan terdapat tombol penyakit organ dan tombol audio.

\subsection{Fitur Halaman Info Penyakit}

Halaman info penyakit merupakan halaman yang menampilkan tentang penyakit yang menyerang organ sesuai dengan objek yang sedang ditampilkan pada dalaman fitur scane marker, untuk mengaktifkan fitur info penyakit maka harus menekan tombol penyakit organ dihalaman scane marker. Pengujian fitur halaman info penyakit ditunjukan pada Gambar 4.5.

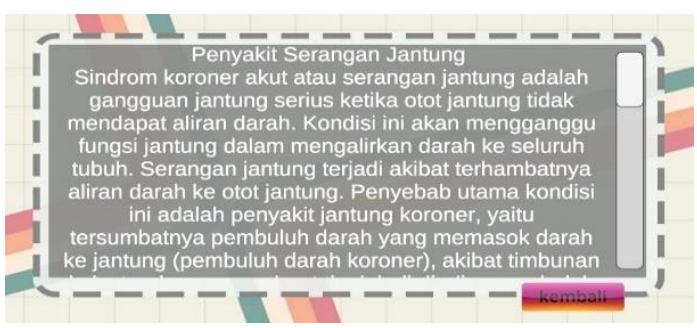

Gambar 4.5 Pengujian fitur info penyakit

Pada Gambar 4.5 ditampilkan halaman fitur info penyakit yang menyampaikan informasi tentang penyakit, penyebab penyakit, dan solusi untuk mengobati penyakit.

\subsection{Pengujian Perangkat Android}

Pengujian perangkat dilakukan untuk mengeteahui kinerja aplikasi saat dijalankan pada smartphone. Pengujian ini dilalukan pada beberapa smartphone dengan spesifikasi berbeda.

Berikut adalah hasil uji coba aplikasi pengenalan organ dalam manusia pada beberapa perangkat seperti pada tabel 4.2 berikut.

Tabel 4.1 Hasil pengujian perangkat Android

\begin{tabular}{|l|c|c|c|c|}
\hline \multicolumn{1}{|c|}{ Merk } & Sistem operasi & RAM & \multicolumn{2}{c|}{ Hasil Uji Coba } \\
\cline { 5 - 6 } & $\begin{array}{c}\text { Status } \\
\text { Install }\end{array}$ & Keterangan \\
\hline Samsung A8 & Pie 9.0.0 & $4 \mathrm{~GB}$ & $\checkmark$ & $\begin{array}{c}\text { Waktu load 3.56 } \\
\text { detik }\end{array}$ \\
\hline $\begin{array}{l}\text { Xiaomi Redmi } \\
\text { Note 5 }\end{array}$ & Pie 9.0.0 & $4 \mathrm{~GB}$ & $\checkmark$ & $\begin{array}{c}\text { Waktu load 4.20 } \\
\text { detik }\end{array}$ \\
\hline $\begin{array}{l}\text { Xiaomi Redmi 2 } \\
\text { Prime }\end{array}$ & Lolipop 5.1.1 & $2 \mathrm{~GB}$ & $\checkmark$ & $\begin{array}{c}\text { Waktu load 10.87 } \\
\text { detik }\end{array}$ \\
\hline Sony Experia Z3 & $\begin{array}{c}\text { Marshmellow } \\
6.0 .0\end{array}$ & $3 \mathrm{~GB}$ & $\checkmark$ & $\begin{array}{c}\text { Waktu load 6.10 } \\
\text { detik }\end{array}$ \\
\hline $\begin{array}{l}\text { Xiaomi Redmi } \\
\text { Note 5 }\end{array}$ & Pie 9.0.0 & $3 \mathrm{~GB}$ & $\checkmark$ & $\begin{array}{c}\text { Waktu load 7.80 } \\
\text { detik }\end{array}$ \\
\hline Samsung J2 Pro & Nouget 7.0.0 & 1.5 & $\checkmark$ & $\begin{array}{c}\text { Waktu load 14.66 } \\
\text { detik }\end{array}$ \\
\hline
\end{tabular}

Kesimpulan dari hasil pengujian aplikasi pada berbagai sistem yang berbeda dapat di simpulkan aplikasi dapat terinstal dan berjalan pada smartphone dengan minimum RAM 1,5 GB dan sistem operasi minimal Lollipop. Saat pengujian dilakukan semua fitur dapat berjalan denganbaik dan sesuai yang diinginkan. 


\subsection{Pengujian Deteksi Marker Dan Pemunculan} Objek

Marker merupakan pemicu untuk aplikasi mengakses database objek. Tiap-tiap marker memiliki rating untuk kecepatan scane-nya, semakin baik kualitas pola marker maka semakin cepat pula waktu scane marker. Hasil pengujain marker dan pemunculan objek ditunjukna pada Gambar 4.6.

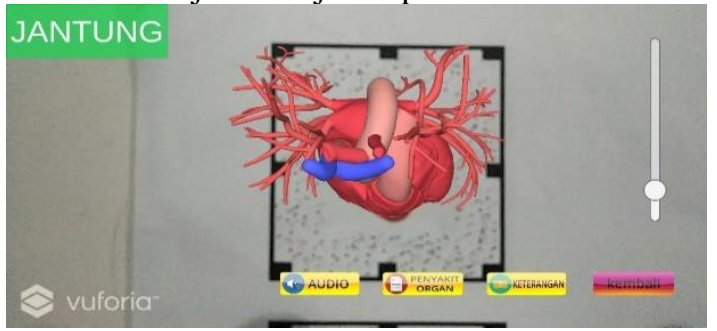

Gambar 4.6 Pengujian marker objek

Pada Gambar 4.6 ditunjukan pengujian marker untuk memunculkan objek jantung. Kesimpulan hasil akhir pengujian marker, semakin unik dan rumit detail marker akan menghasilkan kualitas rating marker yang semakin baik, sehingga dapat menghasilkan waktu scane marker yang cepat juga. Untuk hasil pengujian marker dapat di lihat pada Tabel 4.3.

Tabel 4.2 Pengujian marker dan deteksi objek

\begin{tabular}{|c|c|c|}
\hline \multirow{2}{*}{ No } & \multirow{2}{*}{ Organ } & Keterangan \\
\hline & & Hasil Uji Coba \\
\hline 1. & Jantung & Berhasil dengan waktu load 1.15 detik \\
\hline 2. & Otak & Berhasil dengan waktu load 1.40 detik \\
\hline 3. & Paru-Paru & Berhasil dengan waktu load 2.10 detik \\
\hline 4. & Hati & Berhasil dengan waltu load 1.54 detik \\
\hline 5. & Ginjal & Berhasil dengan waktu load 1.30 detik \\
\hline 6. & Lambung & Berhasil dengan waktu load 1.39 detik \\
\hline 7. & Kantong Empedu & Berhasil dengan waktu load 1.80 detik \\
\hline 8. & Limpa & Berhasil dengan waktu load 2.09 detik \\
\hline 9. & Usus Besar & Berhasil dengan waktu load 1.20 detik \\
\hline 10. & Usus Halus & Berhasil dengan waktu load 1.74 detik \\
\hline 11. & Pankreas & Berhasil dengan waktu load 2.15 detik \\
\hline 12 & Penis & Berhasil dengan waktu load 1.33 detik \\
\hline 13 & 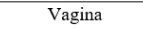 & Berhasil dengan waktu load 1.47 detik \\
\hline
\end{tabular}

Uji coba marker menggunakan marker yang telah dibuat menghasilkan waktu scane yang cepat, dengan hasil semua objek berhasil dimunculkan oleh setiap marker. Kualitas ditentukan otomatis oleh Vuforia dengan rating terkecil adalah 1 dan rating terbesar adalah 5, jadi dapat ditarik kesimpulan rating ideal untuk digunakan adalah makrker dengan rating 4 atau lebih.

\subsection{Pengujian cahaya}

Pengujian intensitas cahaya dilakukan pada tiga kondisi yaitu dengan menggunakan penerangan dari lampu LED 5 watt, lampu LED 20 watt, dan lampu LED 27 watt. Untuk pengujian dapat di lihat pada tabel 4.3.
Tabel 4.3 Pengujian cahaya

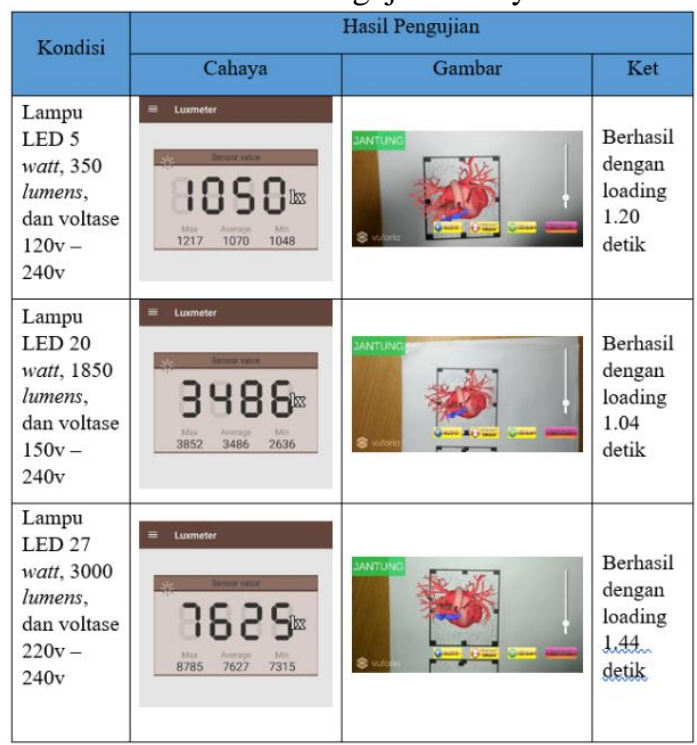

Pengujian dilakukan pada 3 dengan kondisi intesitas cahaya berbeda. Pengujian pertama dilakukan menggunakan penerangan dari lampu LED 5 watt dan voltase $120 \mathrm{v}-240 \mathrm{v}$ dengan intesitas cahaya 350 lumens sedangkan ketika di ukur dengan sensor cahaya didapatkan nilai 1050 lux. Pengujian kedua dilakukan menggunakan penerangan dari lampu LED 20 watt dan voltase $150 \mathrm{v}-240 \mathrm{v}$ dengan intesitas cahaya 1850 lumens sedangkan ketika di ukur dengan sensor cahaya didapatkan nilai 3466 lux. Pengujian ketiga dilakukan menggunakan penerangan dari lampu LED 27 watt dan voltase 220v - 240v dengan intesitas cahaya 3000 lumens sedangkan ketika di ukur dengan sensor cahaya didapatkan nilai 7625 lux. Dari hasil pengujain cahaya, marker dapat dideteksi menggunakan intensitas cahaya didaptakan hasil semua marker dapat terdeteksi dengan jarak cahaya 1050 lux sampai 7625 lux.

\subsection{Pengujian User}

Pengujian pada user atau kuisioner dilakukan untuk mengetahui kepuasan pengguna dalam mengimplementasikan aplikasi pengenalan organ dalam manusia, respond tampilan aplikasi, respond Augmented Reality, respond kemudahan menggunakan aplikasi, dan respond manfaat aplikasi bagi user. Pengujian pengguna di lakukan kepada 20 orang responden. Hasil dari pengujian pengguna dapat di lihat pada Tabel 4.4. 
Tabel 4.4 Hasil pengujian user

\begin{tabular}{|c|l|c|c|c|}
\hline \multirow{2}{*}{ No } & \multicolumn{1}{|c|}{ Pertanyaan } & \multicolumn{3}{|c|}{ Respond Pengguna } \\
\cline { 3 - 5 } & Baik & $\begin{array}{c}\text { Cukup } \\
\text { Baik }\end{array}$ & Kurang \\
\hline 1. & $\begin{array}{l}\text { Bagaimana tampilan pada aplikasi Pengenalan } \\
\text { Organ Dalam Manusia? }\end{array}$ & 11 & 8 & 1 \\
\hline 2. & $\begin{array}{l}\text { Bagaimana informasi yang di sampaikan pada } \\
\text { aplikasi Pengenalan Organ Dalam Manusia? }\end{array}$ & 12 & 6 & 2 \\
\hline 3. & $\begin{array}{l}\text { Bagaimana objek yang di tampilkan pada } \\
\text { aplikasi Pengenalan Organ Dalam Manusia? }\end{array}$ & 14 & 5 & 1 \\
\hline 4. & $\begin{array}{l}\text { Bagaimana kemudahan menggunakan aplikasi } \\
\text { Pengenalan Organ Dalam Manusia? }\end{array}$ & 15 & 5 & - \\
\hline 5 & $\begin{array}{l}\text { Bagaimanakah Aplikasi Pengenalan Organ } \\
\text { Dalam Manusia Membantu Menambah } \\
\text { Pengetahuan Anda Terhadap Organ Dalam } \\
\text { Manusia? }\end{array}$ & 13 & 6 & 1 \\
\hline Jumlah & 65 & 30 & 5 \\
\hline
\end{tabular}

Keterangan :

Dari 20 responden di dapatkan hasil untuk poin 1 mengenai tampilan aplikasi sebanyak 1 reponden mengatakan kurang baik, $40 \%$ responden mengatakan cukup baik, dan $55 \%$ responden mengatakan baik. Kemudian poin 2 mengenai informasi yang di sampaikan oleh aplikasi sebanyak 2 responden mengatakan kurang baik, $30 \%$ responden cukup baik dan $60 \%$ responden mengatakan baik. Untuk poin 3 mengenai objek 3D yang di tampilkan sebanyak 1 responden mengatakan kurang baik, 25\% responden mengatakan cukup baik, dan $70 \%$ responden mengatakan baik. Poin 4 mengenai kemudahan penggunaan aplikasi sebanyak 5 responden mengatakan cukup baik dan 75\% responden mengatakan baik. Untuk poin 5 mengenai bantuan aplikasi dalam menambah pengetahuan tentang organ dalam 1 responden mengatakan kurang baik, 30\% responden mengatakan cukup baik, dan 65\% responden mengatakan baik. Dengan total hasil 65 poin baik, 30 poin cukup baik dan 5 poin kurang.

\section{KESIMPULAN DAN SARAN}

\subsection{Kesimpulan}

Setelah dilakukanya pengujian pada aplikasi Augmented Reality pengenalan organ dalam manusia menggunakan metode marker berbasis Android, maka penulis dapat meyimpulan sebagai berikut :

1. Marker yang dibuat dapat dideteksi oleh aplikasi dengan waktu load 1-2 detik.

2. Aplikasi dan semua fitur dapat berjalan pada smartphone Android dengan minimum sistem operasi Marsmellow 5.0 dan RAM 1,5 GB.

3. Aplikasi memerlukan cahaya yang cukup baik untuk mendeteksi marker yaitu antara 1050 lux 7625 lux.

4. Dari 20 responden hanya 1 pengguna yang menyatakan tampilan aplikasi kurang baik dan 95\% pengguna menyatakan cukup baik atau baik.

5. Dari 20 responden hanya 2 pengguna menyatakan informasi yang disampaikan aplikasi kurang baik dan $90 \%$ pengguna menyatakan cukup baik atau baik.
6. Dari 20 responden hanya 1 pengguna menyatakan bahwa objek yang ditampilkan pada aplikasi kurang baik dan $95 \%$ pengguna menyatakan cukup baik atau baik.

7. Dari 20 responden hanya 2 pengguna menyatakan informasi yang disampaikan aplikasi kurang baik dan $90 \%$ pengguna menyatakan cukup baik atau baik.

8. Dari 20 responden hanya 5 pengguna menyatakan kemudahan penggunaan aplikasi aplikasi cukup baik dan $75 \%$ pengguna menyatakan baik.

9. Dari 20 responden hanya 1 pengguna menyatakan bahwa aplikasi membantu dalam menambah pengetahuan terhadap organ dalam kurang baik dan $95 \%$ pengguna menyatakan cukup baik atau baik.

\subsection{Saran}

Berdasarkan penelitian yang telah dilakukan maka penulis dapat memberikan saran-saran untuk pengembangan selanjutnya karena penelitian ini masih terdapat banyak kekurangan, sehingga untuk penyempurnaan dapat ditambahkan :

1. Menambah lagi objek organ dalam manusia yang belum dimasukan ke dalam aplikasi seperti sistem saraf manusia, otot manusia, sistem kekebalan tubuh, dan lain-lainya.

2. Pembuatan animasi gerakan organ dalam manusia pada objek 3D.

3. Pengembangan ke metode markerless agar penggunaan aplikasi tidak bergantung dengan marker.

\section{DAFTAR PUSTAKA}

[1] Rusnandi, E., Sujadi, H., \& Fauzyah, E. F. N. (2016). Implementasi Augmented Reality (AR) pada Pengembangan Media Pembelajaran Pemodelan Bangun Ruang 3D untuk Siswa Sekolah Dasar. INFOTECH journal, 1(2).

[2] Rifa'i, M., Listyorini, T., \& Latubessy, A. (2014). Penerapan Teknologi Augmented Reality pada aplikasi katalog rumah berbasis android. Prosiding SNATIF, 267-274.

[3] Saputra, A. W., \& Astuti, P. (2018). Rancang Bangun Aplikasi Edukasi Hardware Komputer Berbasis Teknologi Augmented Reality dengan Menggunakan Android. Faktor Exacta, 11(4), 310-321.

[4] Pramono, A., \& Setiawan, M. D. (2019). Pemanfaatan Augmented Reality Sebagai Media Pembelajaran Pengenalan Buah-Buahan. INTENSIF: Jurnal Ilmiah Penelitian dan Penerapan Teknologi Sistem Informasi, 3(1), 54-68.

[5] Rosa, A. C., Sunardi, H., \& Setiawan, H. (2019). Rekayasa Augmented Reality Planet dalam Tata Surya sebagai Media Pembelajaran Bagi Siswa SMP Negeri 57 Palembang. Jurnal Informatika Global, 10(1). 
[6] Salbino, S. (2015). Buku pintar gadget android untuk pemula. Jakarta. KunciKom.

[7] Wahyudi, A. K., Ridi, F., \& Rudy, H. (2013). ARca: Perancangan Buku Interaktif Augmented Reality pada Pengenalan dan Pembelajaran Candi Perambanan dengan Smartphone Berbasis Android. Yogyakarta: Universitas Gajah Mada.

[8] Dewantara, A. Y. (2013). Pengembangan Aplikasi Augmented Reality Book Pengenalan Gerak Dasar Tari Bali. Singaraja: Universitas Pendidikan Ganesha.

[9] Ibañez, A. S., \& Figueras, J. P. (2013). Vuforia v1. 5 SDK: Analysis and evaluation of capabilities. Master in Science in Telecommunication Engineering \& Management.

[10] Yulsilviana, E., Basrie, B., \& Saputra, A. W. (2017). Implementasi Augmented Reality Pemasaran Rumah PT. Rika Bersaudara Sakti Menggunakan Metode Marker Based Tracking Pada Brosur Perumahan. Sebatik, 17(1), 11-15.

[11] Mahmudi, A. (2014). Deteksi Senjata Tajam dengan metode Haar Cascade Classifier Menggunakan Teknologi SMS Gateway. MATICS, 1(1). 